\title{
Hyperlipidaemia and premature coronary artery disease associated with sex-change in a female
}

\author{
C.K. ffrench-Constant*, F.A. Spengel and G.R. Thompson \\ Department of Medicine, Royal Postgraduate Medical School and MRC Lipid Metabolism Unit, Hammersmith \\ Hospital, London W12 OHS, UK.
}

\begin{abstract}
Summary: We describe the management of a genotypic female who developed hyperlipidaemia and premature coronary artery disease following bilateral oophorectomy and methyltestosterone administration, and present evidence to suggest that the therapeutic androgenization involved in the sex-change was responsible for the hyperlipidaemia.
\end{abstract}

\section{Introduction}

Females undergoing oophorectomy before the menopause have an increased incidence of atherosclerosis (Robinson et al., 1959) and an increased all-cause mortality, which is abolished by the use of oestrogens (Bush et al., 1983). The beneficial effect of oestrogens has been attributed in part to their ability to increase high density lipoprotein (HDL)-cholesterol levels in plasma and thus reduce the risk of coronary heart disease (CHD) (Bush et al., 1983). In contrast, androgens are known to affect serum lipoproteins in such a manner as to increase the risk of developing CHD, when given either as methyltestosterone (Russ et al., 1955) or in the form of a progestogen derived from 19-nortestosterone (Hirvonen et al., 1981). It would therefore be expected that a sex-change involving bilateral oophorectomy and the administration of exogenous androgens might result in hyperlipidaemia and premature CHD, although this has not been previously reported. We describe such a case and the subsequent management of these complications.

\section{Case report}

The patient was born a female, with normal establishment of secondary sexual characteristics at puberty. Following increasing transvestite tendencies from age 15 , sex-change was initiated at age 34 , initially sublingual methyltestosterone $(150 \mathrm{mg} / \mathrm{d})$ for two months followed by oral maintenance therapy $(100 \mathrm{mg} / \mathrm{d})$. Following satisfactory virilization, hysterectomy,

C.K. ffrench-Constant, M.A., M.R.C.P.; F.A. Spengel, M.D. (Munich) \& G.R. Thompson, M.D., F.R.C.P.

* Present address: MRC Neuroimmunology Project, Dept of Zoology, University College London, Gower Street, London WCIE 6BT, UK.

Accepted: 29 November 1983 bilateral oophorectomy and bilateral mastectomy were performed.

Three years later, at the age of 37 , the patient developed angina, subsequently sustaining 4 myocardial infarctions between 1975-1977 (age 41-43), following which angina became disabling. Examination in 1978 showed a well virilized, normotensive and obese subject (height $166 \mathrm{~cm}$, weight $71 \mathrm{~kg}$ ) with no stigmata of hyperlipidaemia, who smoked 5 cigarettes a day. There was no family history of CHD and there were no living relatives. Investigation showed serum total cholesterol $9.6 \mathrm{mmol} / 1$ (normal 4.0-6.5), triglyceride $1.8 \mathrm{mmol} / 1$ (normal female $<1.5$ ), high density lipoprotein (HDL) cholesterol $0.65 \mathrm{mmol} / 1$ (normal female 1.02-1.78) and an HDL ratio (HDL/ total cholesterol minus HDL cholesterol) of 0.07 (normal $>0.20$ ). Estimated low density lipoprotein (LDL) cholesterol (Friedewald et al., 1972) was $8.09 \mathrm{mmol} / 1$ (normal $<4.9 \mathrm{mmol} / \mathrm{l}$ ). Haemoglobin, fasting glucose and tests of thyroid and liver function were normal apart from a slight rise in aspartate transaminase (55; normal 7-40 IU/l). ${ }^{99} \mathrm{Tc}$ liver scan was normal. Coronary angiography showed diffuse atheroma with a blocked left anterior descending coronary artery. Methyltestosterone was reduced to $50 \mathrm{mg} / \mathrm{d}$ and two vessel coronary artery bypass grafting was performed, with subsequent relief of angina. Hypercholesterolaemia was managed by clofibrate initially, followed by cholestyramine, with reduction in serum cholesterol to $6.9 \mathrm{mmol} / 1$. In 1979 angina recurred and atenolol was introduced. This was accompanied by increases in both serum cholesterol and triglyceride despite the addition of neomycin. Over this two year period angina remained stable and two further angiograms showed patent grafts.

The patient was re-assessed in 1981 to exclude familial hypercholesterolaemia. Skin fibroblast cul- 
ture showed normal HMG-CoA reductase activity $(4.8 \mathrm{pmol} / \mathrm{mg} / \mathrm{min}$; normal $0.18-5.70)$ and a normal cholesterol ester: total cholesterol ratio $(0.13$; normal $0.09-0.24)$, indicating normal LDL receptor activity and thus excluding familial hypercholesterolaemia (Spengel et al., 1982).

Because of the patient's refusal to discontinue androgens and our failure to control hyperlipidaemia by drugs, a partial ileal bypass was performed ( $\mathrm{Mr} \mathrm{C}$. Wood). Operative liver biopsy showed some perivenous hepatocyte hyperplasia but no evidence of cholestasis. Three months later serum cholesterol was $6.1 \mathrm{mmol} / \mathrm{l}$, LDL-cholesterol $4.8 \mathrm{mmol} / \mathrm{l}$, HDLcholesterol $0.55 \mathrm{mmol} / \mathrm{l}$ and the HDL ratio was 0.1 . Turnover studies of ${ }^{125}$ I-LDL and ${ }^{131}$ I-LDL-cyclohexanedione (Shepherd et al., 1979) before and 3 months after surgery showed an increase in the total fractional catabolic rate of LDL protein from 0.259 to $0.358 / \mathrm{d}$, with the proportion catabolized via the receptormediated pathway increasing from $25 \%$ to $39 \%$, and a decrease in LDL synthesis from 12.3 to $9.2 \mathrm{mg} / \mathrm{kg} / \mathrm{d}$. All the post-operative indices of LDL turnover are within the normal range. Two years later the patient remains well with stable angina and the serum cholesterol and LDL-cholesterol are both normal. HDLcholesterol has risen to $1.30 \mathrm{mmol} / \mathrm{l}$ and the $\mathrm{HDL}$ ratio is now normal $(0.277)$.

\section{Discussion}

This patient's therapeutic virilization was associated with hypercholesterolaemia, low HDL-cholesterol and raised LDL-cholesterol. The hormonal manipulation is a likely cause for these changes. Bilateral oophorectomy in premenopausal women is associated with a significant increase in serum cholesterol and a fall in the ratio of HDL to LDL cholesterol (Robinson et al., 1957). Methyltestosterone in hyperlipaemic men raised cholesterol by $30 \%$, lowered HDL by $55 \%$ and raised LDL by $11 \%$ (Oliver \& Boyd, 1956). A similar study (Russ et al., 1955) showed a fall in the HDL/ LDL ratio after androgens with no consistent effect on total serum cholesterol. A solitary oophorectomized

\section{References}

ANGELIN, B., RAVIOLA, C.A., INNERARITY, T.L. \& MAHLEY, R.W. (1983). Regulation of hepatic lipoprotein receptors in the dog. Rapid regulation of apolipoprotein $B$, $\mathrm{E}$ receptors, but not of apolipoprotein $\mathrm{E}$ receptors, by intestinal lipoproteins and bile acids. Journal of Clinical Investigation, 71, 816.

BUSH, T.L. COWAN, L.D., BARRETT-CONNOR, E., CRIQUI, M.H., KARON, J.M., WALLACE, R.B., TYROLER, H.A. \& RIFKIND, B.M. (1983). Estrogen use and all-cause mortality. Preliminary results from the lipid research clinics female given methyltestosterone following oestrone showed a similar fall in the HDL/LDL ratio although 3 the total cholesterol fell (Furman \& Howard, 1957). $\stackrel{\mathbb{Q}}{\stackrel{2}{\complement}}$ The lowered HDL and increased LDL is therefore a $C$. consistent feature of methyltestosterone therapy, alth- $\vec{\Rightarrow}$. ough effects on total cholesterol are contradictory.

There is no evidence for other factors producing hyperlipidaemia in this patient. Unfortunately there is $\frac{\bar{F}}{\bar{D}}$ no record of serum lipids being determined before sex- $\frac{\sigma}{\sigma}$ change but the presence of normal LDL receptor $\stackrel{\mathbb{Q}}{\circ}$ activity in fibroblasts excludes familial hypercholesterolaemia. Long term methyltestosterone can $\vec{\circ}$

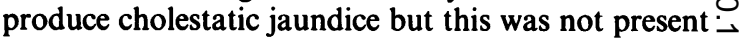
in our patient, whose only abnormality on liver biopsy $\vec{\omega}$ was slight perivenous hepatocyte hyperplasia. This is $\frac{\mathrm{S}}{\mathrm{O}}$ consistent with changes previously reported in othero patients on this androgen (Westaby et al., 1977).

The response to partial ileal bypass was similar to $\stackrel{9}{-}$ that reported by Spengel et al. (1981) in patients with $\checkmark$ familial hypercholesterolaemia. LDL turnover studies $\overrightarrow{-}$ showed an increase in receptor-mediated catabolism $\stackrel{-}{-}$ consistent with an increase in the activity of hepatic 응 LDL receptors resulting from increased conversion of cholesterol to bile acids (Angelin et al., 1983), as occurs after partial ileal bypass (Moore et al., 1969). It is hoped that the complete normalization of this patient's serum lipids and HDL ratio two years after $\vec{\circ}$ partial ileal bypass, despite maintenance of testo $\odot$ terone therapy, will prevent the onset of the at or eromatous changes observed in the vein grafts patients whose hyperlipidaemia persists following coronary artery bypass surgery (Palac et al., 1982).

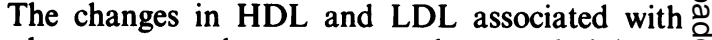
oophorectomy and exogenous androgen administra- $\stackrel{\mathbb{Q}}{\stackrel{\mathrm{Q}}{\Omega}}$ tion would be expected to increase the risk of CHD $\underset{F}{\rightleftharpoons}$ (Miller et al., 1977), and presumably caused the $\frac{\circ}{3}$ premature coronary disease observed in this 37 year old patient, whose only other risk factor was a very modest consumption of cigarettes. We conclude that females undergoing artificial virilization may well 3 . constitute a high risk group for premature CHD and $\bar{\sigma}$ should be carefully assessed for hyperlipidaemia on this account.

program follow-up study. Journal of the American Medical $\stackrel{N}{\sigma}$ Association, 249, 903.

FRIEDEWALD, W.T., LEVY, R.I. \& FREDRICKSON, D.S. సి (1972). Estimation of the concentration of low-density $\omega$ lipoprotein cholesterol in plasma, without use of the preparative ultracentrifuge. Clinical Chemistry, 18, 499 .

FURMAN, R.H. \& HOWARD, R.P. (1957). The influence of $\mathbb{Ð}$ gonadal hormones on serum lipids and lipoproteins: ? studies in normal and hypogonadal subjects. Annals of $\square$ Internal Medicine, 47, 969. 
HIRVONEN, E., MÄLKÖNEN, M. \& MANNINEN, V. (1981). Effects of different progestogens on lipoproteins during postmenopausal replacement therapy. New England Journal of Medicine, 304, 560.

MILLER, N.E., FØRDE, O.H., THELLE, D.S. \& MJøS, O.D. (1977). The Tromsø heart study. High density lipoprotein and coronary heart disease: A prospective case-control study. Lancet, i, 965.

MOORE, R.B., FRANTZ, I.D. \& BUCHWALD, H. (1969). Changes in cholesterol pool size, turnover rate, and fecal bile acid and sterol excretion after partial ileal bypass in hypercholesteremic patients. Surgery, 65, 98.

OLIVER, M.F. \& BOYD, G.S. (1956). Endocrine aspects of coronary sclerosis. Lancet, ii, 1273.

PALAC, R.T., MEADOWS, W.R., HWANG, M.H., LOEB, H.S., PIFARRE, R. \& GUNNAR, R.M. (1982). Risk factors related to progressive narrowing in aorto-coronary vein grafts studied 1 and 5 years after surgery. Circulation, 66, (suppl. I), 40.

ROBINSON, R.W., HIGANO, N. \& COHEN W.D. (1957). The effects of estrogens on serum lipids in women. A.M.A. Archives of Internal Medicine, 100, 739.
ROBINSON, R.W., HIGANO, N. \& COHEN W.D. (1959). Increased incidence of coronary heart disease in women castrated prior to the menopause. A.M.A. Archives of Internal Medicine, 104, 908.

RUSS, E.M., EDER, H.A. \& BARR, D.P. (1955). Influence of gonadal hormones on protein-lipid relationships in human plasma. American Journal of Medicine, 19, 4.

SHEPERD, J., BICKER, S., R. LORIMER, A.R. \& PACKARD, C.J. (1979). Receptor-mediated Low density lipoprotein catabolism in man. Journal of Lipid Research, 20, 999.

SPENGEL, F.A., JADHAV, A., DUFFIELD, R.G.M., WOOD, C.B. \& THOMPSON, G.R. (1981). Superiority of partial ileal bypass over cholestyramine in reducing cholesterol in familial hypercholesterolaemia. Lancet, ii, 768.

SPENGEL, F.A., HARDERS-SPENGEL, K.M., KELLER, C.F., WIECZOREK, A., WOLFRAM, G. \& ZÖLLNER, N. (1982). Use of fibroblast culture to diagnose and genotype familial hypercholesterolaemia. Annals of Nutrition and Metabolism, 26, 240.

WESTABY, D., OGLE, S.J., PARADINAS, F.J., RANDELL, J.B. \& MURRAY-LYON, I.M. (1977). Liver damage from longterm methyltestosterone. Lancet, ii, 261. 